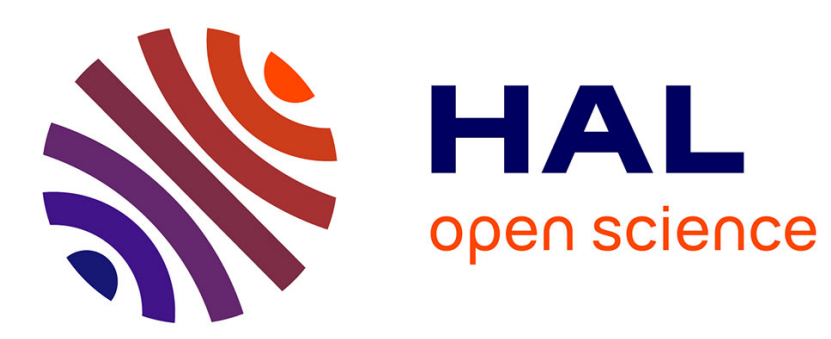

\title{
Influence of heat treatment on the microstructure and properties of laser welds in 8090
}

\author{
I. Whitaker, N. Calder, D. Mccartney, W. Steen
}

\section{To cite this version:}

I. Whitaker, N. Calder, D. Mccartney, W. Steen. Influence of heat treatment on the microstructure and properties of laser welds in 8090. Journal de Physique IV Proceedings, 1993, 03 (C7), pp.C71053-C7-1056. 10.1051/jp4:19937163 . jpa-00251787

\section{HAL Id: jpa-00251787 https://hal.science/jpa-00251787}

Submitted on 1 Jan 1993

HAL is a multi-disciplinary open access archive for the deposit and dissemination of scientific research documents, whether they are published or not. The documents may come from teaching and research institutions in France or abroad, or from public or private research centers.
L'archive ouverte pluridisciplinaire HAL, est destinée au dépôt et à la diffusion de documents scientifiques de niveau recherche, publiés ou non, émanant des établissements d'enseignement et de recherche français ou étrangers, des laboratoires publics ou privés. 


\title{
Influence of heat treatment on the microstructure and properties of laser welds in 8090
}

\author{
I.R. WHITAKER, N.J. CALDER*, D.G. MCCARTNEY and W.M. STEEN** \\ Department of Materials Engineering and Materials Design, University of Nottingham, U.K. \\ 'Manufacturing Technology, Military Aircraft Division, British Aerospace Defence Ltd., Warton, \\ Lancashire, U.K. \\ ${ }^{* *}$ Department of Mechanical Engineering, University of Liverpool, U.K.
}

\begin{abstract}
An investigation into the weldability of the $\mathrm{Al}-\mathrm{Li}-\mathrm{Cu}-\mathrm{Mg}-\mathrm{Zr}$ alloy 8090 using a $\mathrm{CO}_{2}$ laser indicates that the grain structure and microstructure of the weld zone are sensitive to the post-weld heat treatment. If a slow heating rate of $1 \mathrm{Kmin}^{-1}$ to the solution treatment temperature is used the formation of $\beta^{\prime}\left(\mathrm{Al}_{3} \mathrm{Zr}\right)$ dispersoids is promoted which leads to a uniformly small grain size within the fusion zone. If, however, faster heating rates are employed massive grains can form in the fusion zone. This is shown to be associated with a virtual absence of $\boldsymbol{\beta}^{\prime}$ precipitates.
\end{abstract}

\section{INTRODUCTION}

The Al-Li alloy 8090 with a nominal composition of $\mathrm{Al}-2.4 \mathrm{wt} \% \mathrm{Li}-1.1 \mathrm{wt} \% \mathrm{Cu}-0.6 \mathrm{wt} \% \mathrm{Mg}-0.1 \mathrm{wt} \% \mathrm{Zr}$ is a low density, high modulus precipitate strengthened alloy whose mechanical properties are governed by the volume fraction, size and distribution of the strengthening phases. A small amount of $\mathrm{Zr}$ is added to 8090 during the alloy manufacture in order to form the metastable, coherent dispersoid $\beta^{\prime}\left(\mathrm{Al}_{3} \mathrm{Zr}\right)$. This phase is responsible for maintaining a fine grain size during hot working(1). The $\delta^{\prime}\left(\mathrm{Al}_{3} \mathrm{Li}\right)$ phase which forms on ageing is the major strengthening precipitate. It forms with a bi-modal size distribution as either homogeneous, spherical particles or as a 'composite' precipitate on a core of $\beta^{\prime}(2)$.

The possibility of using $\mathrm{Al}-\mathrm{Li}$ alloys in aerospace applications, as storage tanks for example, has seen the development of Al-Li welding research which has been reviewed with respect to conventional techniques(3) and also with specific emphasis on the use of the laser beam(4). It has been shown that Al-Li alloys can be laser welded but are quite susceptible to fusion zone porosity.

During welding the prior thermomechanical treatment applied to the alloy is erased and an as-solidified microstructure forms in the fusion zone. The mechanical properties of the fusion zone are then significantly different from those of the base metal. It is the purpose of this paper to demonstrate that the structure of the laser welded fusion zone can be controlled and optimised by the application of a suitable, post-weld thermal treatment.

EXPERIMENTAL PROCEDURE

The basic experimental procedure for laser welding superplastically formable (SPF) grade alloy 8090 has been described previously(4). In this study weld samples in $4 \mathrm{~mm}$ sheet were subjected to different post-weld heat treatments. In the first set of experiments each sample was placed directly into a fan oven which had been preheated to the solution treatment temperature required. Temperatures ranging from 460 to $530^{\circ} \mathrm{C}$ were investigated. The measured heating rate to the solutionising temperature was approximately $100 \mathrm{Kmin}^{-1}$, and the time at temperature was 40 minutes.

In a second set of experiments each sample was heated to the same solutionising temperature of $530^{\circ} \mathrm{C}$ but additional heating rates of 1 and $10 \mathrm{Kmin}^{-1}$ were investigated. For comparative purposes base metal samples were also subjected to these heat treatments. Samples were examined by optical and transmission electron microscopy (TEM) in the solution treated condition and also after artificial ageing (at $190^{\circ} \mathrm{C}$ for 16 hours). Samples for TEM were taken from longitudinal weld centre-line sections. The narrow weld bead was cut from the surrounding metal and carefully ground to a thickness of $\sim 500 \mu \mathrm{m}$. Discs $3 \mathrm{~mm}$ in diameter were trepanned and ground further to a thickness of $-100 \mu \mathrm{m}$. Thin foils were obtained through twin jet polishing in a solution of $25 \%$ nitric acid in methanol at $-30^{\circ} \mathrm{C}$ with an applied voltage of $12 \mathrm{~V}$ producing a current of $0.1 \mathrm{~A}$. Diffraction analysis was conducted 
at $100 \mathrm{kV}$ on a Philips EM301 whilst qualitative compositional analysis was performed at 200kV on a JEOL 2000FXII equipped with an energy dispersive X-ray (EDX) detector. Optical microscopy of etched samples was used to assess the effect of heat treatment on $\alpha$-Al grain size within the weld, and values of Vickers microhardness were also measured. In addition differential thermal analysis (DTA) of selected samples was undertaken at heating rates of 10 and $50 \mathrm{Kmin}^{-1}$ up to $650^{\circ} \mathrm{C}$.

\section{3}

\section{RESULTS}

The laser welding technique and the microstructure of the as-solidified laser weld have recently been reviewed in a previous paper(4) and will not be considered here. The results in this section are presented in three parts as follows: (1) the effect of solution treatment temperature, (2) the effect of heating rate to the solution treatment temperature and (3) the influence of ageing treatments, on weld metal microstructure and microhardness.

\subsection{Effect of solution treatment temperature}

For the range of solution treatment temperatures and times employed marked changes to the as-solidified weld structure were first observed optically at $470^{\circ} \mathrm{C}$. As the treatment temperature increased homogenisation became more complete, but the most notable change which occurred was to the average grain size which increased from $\sim 10 \mu \mathrm{m}$ at $470^{\circ} \mathrm{C}$ to around $25 \mu \mathrm{m}$ at $530^{\circ} \mathrm{C}$. Fig. 1 is an optical micrograph of a weld, heat treated at $530^{\circ} \mathrm{C}$, and massive grains measuring up to $200 \mu \mathrm{m}$ can be seen. These were predominantly at the fusion zone/base metal boundary but could also be found within the body of the weld. The Vickers microhardness of the fusion zone showed a clear increase with solutionising temperature which probably reflects the more extensive homogenisation at higher temperatures.

\subsection{Effect of heating rate}

The grain structure of the weld fusion zone was found to be strongly dependent on the heating rate to the solution treatment temperature as shown by the micrographs in Figs. 1 and 2. The average grain size was found to decrease from around $25 \mu \mathrm{m}$ to $10.0 \pm 1.2 \mu \mathrm{m}$ as the heating rate decreased from 100 to $1 \mathrm{Kmin}^{-1}$. Centred dark field micrographs from $\delta^{\prime}$ reciprocal lattice spots, illustrated in Fig. 3 , show that $\boldsymbol{\delta}^{\prime}$ has precipitated during air cooling with a significant bi-modal distribution in the $1 \mathrm{Kmin}^{-1}$ sample of Fig. 3(a). EDX analysis of the larger precipitate cores confirmed that they were enriched in $\mathrm{Zr}$. In contrast, $\delta^{\prime}$ has precipitated in a distinctly more homogeneous manner after a heating rate of $100 \mathrm{Kmin}^{-1}$, Fig. 3(b). The average microhardness of the fusion zone increased from $\sim 95 \mathrm{kgfmm}^{-2}$ to $\sim 120 \mathrm{kgfmm}^{-2}$ as the heating rate was decreased from 100 to $1 \mathrm{Kmin}^{-1}$. This is probably caused by enhanced homogenisation during the slow heating to the solution treatment temperature. DTA was performed on weld metal with heating rates of 10 and $50 \mathrm{Kmin}^{-1}$ which showed that the onset of melting was at $574^{\circ} \mathrm{C}$ in both cases, i.e. well above the solution treatment temperature.

\subsection{Effect of ageing treatment}

TEM was performed on weld metal which had been

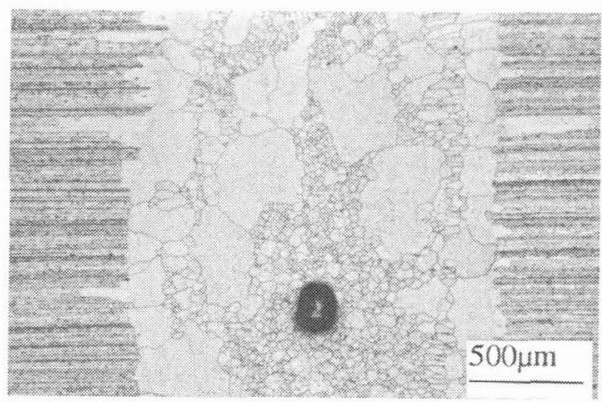

Figure 1 Optical micrograph of a weld heated at $100 \mathrm{Kmin}^{-1}$ to $530^{\circ} \mathrm{C}$.
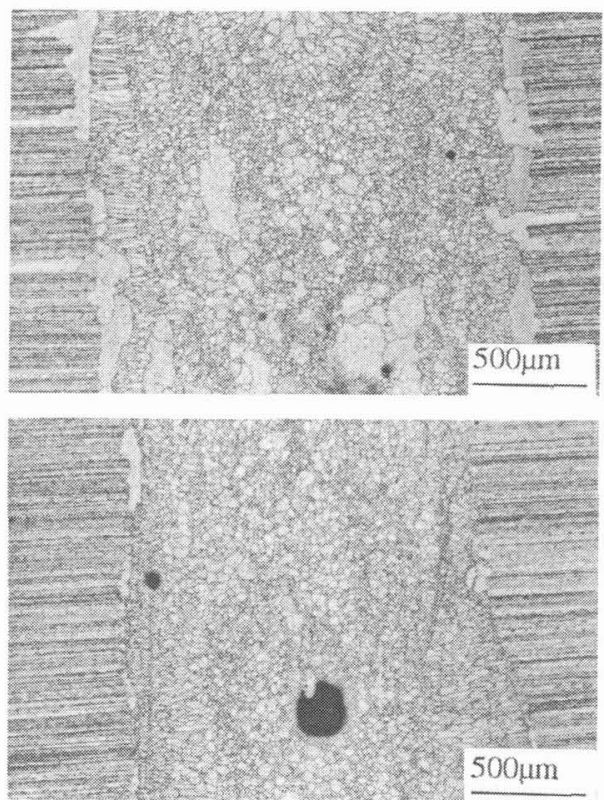

Figure 2 Optical micrographs of solution treated welds after heating rates of (a) $10 \mathrm{Kmin}^{-1}$ and (b) $1 \mathrm{Kmin}^{-1}$.

(a) post-weld aged for 16 hours at $190^{\circ} \mathrm{C}$ and (b) solution treated with heating rates of 100 and $1 \mathrm{Kmin}^{-1}$ followed 
by ageing for 16 hours at $190^{\circ} \mathrm{C}$.

The centred dark field micrograph of Fig. 4 taken from the post-weld aged sample illustrates that the $\delta^{\prime}$ distribution is uni-modal with enhanced precipitation at the $\alpha$ Al cell boundaries compared to the cell centres. The precipitate diameter is $-30 \mathrm{~nm}$. After heating at a rate of $100 \mathrm{Kmin}^{-1}$, solution treating and ageing a largely uni-modal distribution of $\delta^{\prime}$ precipitates was observed throughout the microstructure together with a small amount of $\mathrm{S}^{\prime}\left(\mathrm{Al}_{2} \mathrm{CuMg}\right)$ phase, Fig. 5(a). After heating at a rate of $1 \mathrm{Kmin}^{-1}$, solution treating and ageing the microstructure consisted of a bi-modal $\delta^{\prime}$ distribution, Fig. 5(b). Large duplex precipitates with reduced contrast cores measuring $\sim 90 \mathrm{~nm}$ in diameter were observed at grain boundaries and within grains. EDX analysis of the cores confirmed that they were enriched in $\mathbf{Z r}$. Microhardness measurements of the weld metal in these heat treatment conditions were made and are summarised in the graph of Fig. 6. In the as-welded condition the weld is marginally harder then the SPF grade base metal. When aged the weld hardens more than the base metal. Only when solution treated and aged do base and weld metal attain similar hardnesses.

\section{DISCUSSION}

One of the purposes of the discussion is to examine the underlying mechanisms responsible for the marked effect of heating rate on grain size in the solution treated welds as evidenced by Figs. 1 and 2. The DTA work performed, on sections taken from the welds, showed that the onset of melting occurred some $40 \mathrm{~K}$ above the solution treatment temperature and hence localized grain boundary melting could not have played a part. However, the TEM studies using centred dark field imaging techniques have confirmed that there was a clear difference in $\beta^{\prime}$ distribution between the samples subjected to different heating rates as seen by comparing Figs. 3(a) and (b).

$\beta^{\prime}$ is known to inhibit grain boundary migration(5) and was clearly effective in the sample heated at $1 \mathrm{Kmin}^{-1}$. On the contrary, it would appear that in the more rapidly heated samples there was insufficient time available for appreciable amounts of $\beta^{\prime}$ to nucleate and grow(6). Hence grain boundary migration was possible and led to abnormal grain growth giving some massive grains. The latter were most frequently formed in regions of prior columnar grains. The common $<100\rangle$ growth direction of these columnar grains might well have played a role in enabling massive grains to develop. The centred dark field images of the aged samples shown in Figs. 4 and 5 confirm these observations regarding $\beta^{\prime}$ precipitation. On ageing $\delta^{\prime}$ can grow on existing, large $\beta^{\prime}$ particles(2) and clearly delineates the latter.

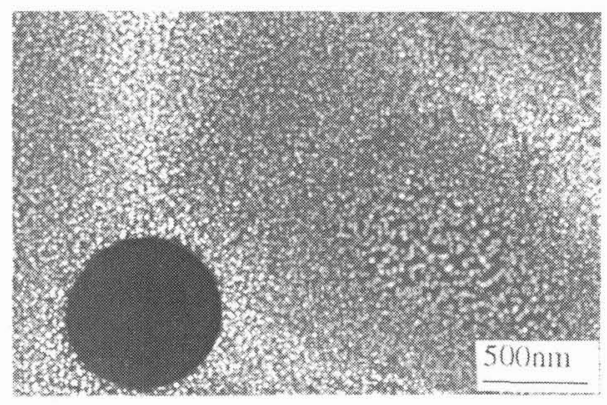

Figure $4 \delta^{\prime}$ dark field image of a weld aged for 16 hours at $190^{\circ} \mathrm{C}$.

\section{No $\beta^{\prime}$ can be seen in Figs. 4 or 5(a) whereas in Fig. 5(b)}

(from the weld heated at $1 \mathrm{Kmin}^{-1}$ ) numerous duplex $\beta^{\prime} / \delta^{\prime}$ particles are visible. The dependence of dispersoid distribution on heating rate has been noted previously in an $\mathrm{Al}, \mathrm{Mg}, \mathrm{Zn}$ alloy containing $0.3 \mathrm{wt} \% \mathrm{Mn}$ by Thomas(7).

Turning now to the microstructure, microhardness values correlate well with the TEM observations on $\delta^{\prime}$ formation. In the as-welded condition the low hardness is due to the small volume fraction of $\delta^{\prime}$ and its uneven distribution arising from microsegregation during solidification. After post-weld ageing the $\delta^{\prime}$ distribution is shown in Fig. 4. The volume fraction of $\delta^{\prime}$ is large, but it is still non-uniformly distributed. In this post-weld aged condition the fine-scale, rapidly solidified laser weld has hardened significantly more than the SPF grade base metal 

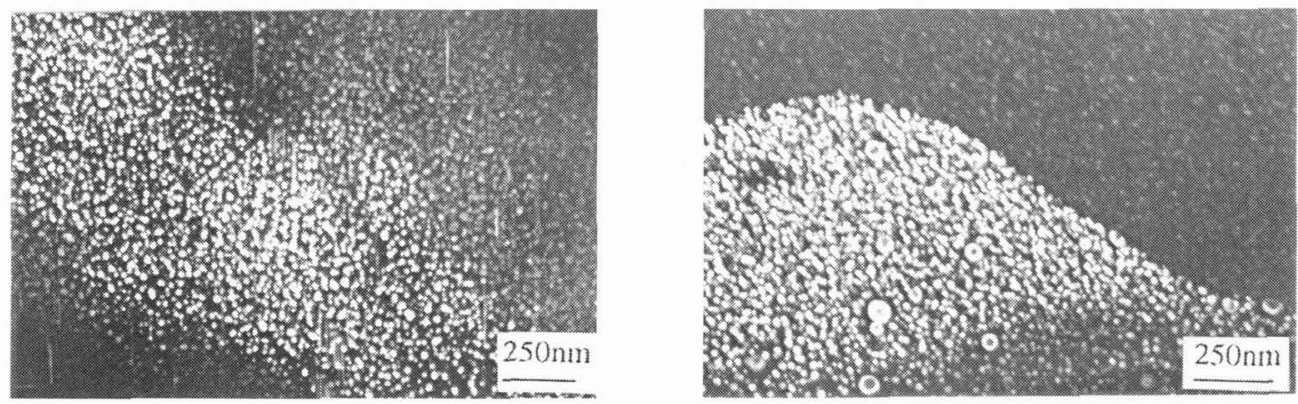

Figure $5 \delta^{\prime}$ dark field images from solution treated and aged welds after employing heating rates of (a) $100 \mathrm{Kmin}^{-1}$ and (b) $1 \mathrm{Kmin}^{-1}$.

with its initially rather coarse intermetallic phase distribution(4). Only after a full solution treatment and ageing (ST+A) was it possible to achieve approximately equal hardnesses of weld and base metal. In this ST+A condition the heating rate had no significant effect on microhardness, but as noted previously had a major effect on grain size. Since base metal and weld can reach the same hardness after ST+A, it would appear that little lithium is lost during the autogenous bead-on-plate laser welding process.

\section{5}

\section{CONCLUSIONS}

From the work undertaken it can be concluded that the as-welded structure is sensitive to the solution treatment temperature and the heating rate to the solution treatment temperature. Grain size and microhardness measurements have clearly illustrated that the weld properties can be optimised by adopting a slow heating rate of $1 \mathrm{Kmin}^{-1}$ to $530^{\circ} \mathrm{C}$. The suggested mechanism responsible for preventing widespread grain growth during solution treatment is the formation of the dispersoid $\beta^{\prime}$ which precipitates during slow heating and pins the grain boundaries.

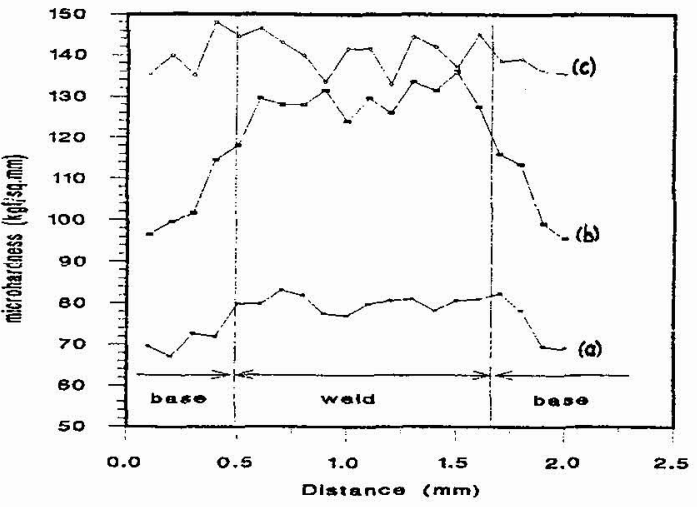

Figure 6 Microhardness profiles off (a) as-welded, (b) aged and (c) solution treated and aged samples.

\section{ACKNOWLEDGEMENTS}

This work was supported by the Science and Engineering Research Council and British Aerospace through a Co-operative Research Grant and CASE award research studentship.

\section{REFERENCES}

[1] E. Nes, Metal Science, March-April (1979) 211-215.

[2] P.J. Gregson and H.M. Flower, J. of Mat. Sci. Lett., 3 (1984) 829-834.

[3] J.R. Pickens, J. of Mat. Sci., 25 (1990) 3035-3047.

[4] I.R. Whitaker, N.J. Calder, D.G. McCartney and W.M. Steen, J. of Mat. Sci., (in press).

[5] E. Nes, N. Ryum and O. Hunderi, Acta Metall., 33 (1985) 11-22.

[6] M.S. Zedalis and M.E. Fine, Met. Trans. A, 17A (1986) 2187.

[7] A.T. Thomas, Proc. Sixth Int. Conf. on Light Metals, Leoban/Vienna, Aluminium-Verlag, GMBH, 1975, pp. 58-60. 